\title{
Effects of Powdery Mildew on Vine Growth, Yield, and Quality of Concord Grapes
}

\author{
David M. Gadoury, Robert C. Seem, Roger C. Pearson, and Wayne F. Wilcox, Department of Plant Pathology, \\ Cornell University, New York State Agricultural Experiment Station, Geneva, 14456; and Richard M. Dunst, \\ Vineyard Research Laboratory, Cornell University, New York State Agricultural Experiment Station, Fredonia \\ 14063
}

\begin{abstract}
Gadoury, D. M., Seem, R. C., Pearson, R. C., Wilcox, W. F., and Dunst, R. M. 2001. Effects of powdery mildew on vine growth, yield, and quality of Concord grapes. Plant Dis. 85:137-140.

Vitis labruscana 'Concord' is a widely planted grape cultivar grown in the United States for processing into juice and other products. Concord fruit are sporadically but sometimes severely damaged by the grape powdery mildew pathogen, Uncinula necator. The effects of powdery mildew on vine growth, yield, and quality of Concord grapes at three levels of cropping intensity commonly found in commercial grape production were determined in vineyard studies. Top-wire cordon-trained Concord vines were balance pruned, pruned to retain 80 nodes, or minimally pruned. Replicated plots of the foregoing were then either protected from powdery mildew by regular fungicide applications, or were inoculated and left unsprayed. Over a 4-year period, the effects of foliar infection on vine growth, yield, and juice quality of unsprayed vines were compared with vines that received a conventional protection program of four fungicide applications. Failure to control powdery mildew resulted in a chronic reduction in wood maturity measured as the number of nodes on canes that developed periderm. The reduction in nodes did not reduce yield, possibly due to compensation in shoots produced from the remaining nodes. Powdery mildew did not affect bud survival or vigor, measured as the number of shoots produced per node on retained canes. The most significant effects of powdery mildew were on berry sugar levels and juice color and acidity, which on the unsprayed vines were sometimes reduced below minimally acceptable thresholds for processed grapes. Significant reductions due to powdery mildew in these parameters occurred in all three pruning treatments, but were most pronounced at higher cropping levels.
\end{abstract}

Additional keywords: disease management, Oidium

Powdery mildew is the most widespread and destructive disease of grapevines worldwide (15). Much of what is known of the damage caused by the pathogen, Uncinula necator (Schw.) Burr., has been learned from studies of the disease on cultivars of the European grape species, Vitis vinifera. Most cultivars of $V$. vinifera bear leaves and fruit that are highly susceptible to this pathogen (15). Concord grapes are of the species Vitis labruscana, which is native to North America, and are generally thought to be more resistant to powdery mildew than are cultivars of $V$. vinifera $(15,16)$. Concord grapes are widely planted throughout the states of New York, Pennsylvania, Ohio, Michigan, and Washington where they are processed into both fermented and nonfermented products. Despite the widespread culture of Concord grapes, and the routine use of fungicides to

Corresponding author: D. M. Gadoury

E-mail: dmg4@ cornell.edu

Accepted for publication 18 September 2000.

Publication no. D-2000-1120-03R

(c) 2001 The American Phytopathological Society suppress powdery mildew on this cultivar, there is little known of the magnitude of the effects of powdery mildew on vine growth, yield, and quality of Concord grapes. Previous estimates of the impact of powdery mildew on yield and quality of Concord grapevines $(9,17)$ relied on a combination of unpublished data and estimates extrapolated from other grape cultivars, whereas other reports have addressed only the incidence and severity of disease on leaves or fruit $(13,17,19)$, without concomitant data on vine growth, yield, and crop quality.

Recent studies on the development of powdery mildew on Concord grapevines suggest that fruit are only briefly susceptible to infection by $U$. necator (6), that foliar infection has a minimal impact on net photosynthesis (11), and that reducedspray programs are adequate to produce mildew-free fruit (5). The effects of other chronic stress factors, such as drought (10) or insect feeding (12), on yield and crop quality may accumulate during a single growing season or over successive years and are likely to be of the greatest magnitude as crop loads increase, e.g., due to minimal pruning $(10,12)$. Nevertheless, the impact of chronic powdery mildew infec- tion on the long-term growth, yield, and crop quality of Concord grapevines remains unknown. Such information is needed by IPM programs, regulatory agencies, and growers to realistically evaluate the purported benefits of fungicide use to control powdery mildew on this cultivar. Our objective was to examine the effects of powdery mildew on vine growth, yield, and crop quality of Concord grapevines at three different cropping levels.

\section{MATERIALS AND METHODS}

Plots were established in 1992 in a 30year-old top-wire cordon-trained Concord vineyard at Cornell University's Vineyard Research Lab in Fredonia, NY. The vineyard was composed of 12 rows with 24 vines per row. Spacing between vines was $2.4 \mathrm{~m}$, and $2.7 \mathrm{~m}$ between rows.

Three different pruning levels were imposed in a random complete block design within the vineyard: balance pruned, 80node pruned, and minimally pruned. During each year of the study, vines were first pruned while dormant to the approximate desired number of nodes, and the prunings were weighed. For balance-pruned vines, 44 nodes were retained per $\mathrm{kg}$ of cane pruning weight. In the 80-node treatments, vines were pruned to 80 nodes per vine, irrespective of the previous season's cane growth. For the minimal-pruned treatment, all pendant canes were cut horizontally $0.9 \mathrm{~m}$ above ground level, and all laterally growing canes were cut vertically midway $(1.2 \mathrm{~m})$ between the trunks of adjacent vines.

Treatment blocks were three rows wide. Each three-row block was then split into two levels of powdery mildew control: four applications of myclobutanil (112 $\mathrm{g} / \mathrm{ha}$ ) at 2-week intervals beginning just prior to first bloom, or unsprayed and inoculated with conidia of $U$. necator. Each replicate plot consisted of the 12 vines within one-half of a row, and all treatments were replicated four times.

Inoculation and disease assessments. A single-conidial isolate (Concord-F-DC) obtained from Concord grapevines in Fredonia whose pathogenicity was described in a previous study (4) was maintained in isolation on $V$. labruscana seedlings. A uniform intensity of primary infection was established on unsprayed control vines by inoculating leaves with conidia from this isolate of $U$. necator when shoots were 
approximately 10 to $15 \mathrm{~cm}$ long each spring. From diseased 4-week-old $V$. labruscana seedlings maintained in a greenhouse, conidia of $U$. necator were harvested into distilled water plus the surfactant Tween $20(0.05 \mathrm{ml} / \mathrm{liter})$, diluted to a concentration of $10^{5}$ conidia per $\mathrm{ml}$, and applied within $30 \mathrm{~min}$ of preparation. On five shoots per vine, the conidial suspension was atomized onto the youngest fully expanded leaf until droplets became visible on the upper surface. The suspension dried within $10 \mathrm{~min}$ after the spray application. Sporulating colonies developed from these inoculations within 14 days in each year of the study. Germination of conidia from the applied suspensions was assessed by spraying three glass microscope slides in the vineyard with the remnants of the suspension, allowing them to dry, and then incubating the slides at $25^{\circ} \mathrm{C}, 90$ to $95 \%$ relative humidity for $24 \mathrm{~h}$, after which the slides were examined at $400 \times$. Germination or the lack thereof was noted for 100 conidia per slide.

Disease incidence and severity were assessed visually immediately before harvest in each year of the study. Foliar disease incidence was recorded as the number of infected leaves per shoot on five shoots on each of eight vines per replicate plot. Foliar disease severity was recorded as the percentage of the leaf surface colonized by $U$. necator on each infected leaf. The percentage of the cluster surface colonized was also recorded on 10 fruit clusters on each of eight vines per plot.
Assessment of vine growth, yield, and juice quality. As a measure of wood maturity, the number of nodes with periderm was counted on each vine prior to dormantseason pruning. After pruning, the cane prunings were weighed and the number of nodes retained on the minimally pruned vines was counted. At 7 to $12 \mathrm{~cm}$ shoot growth the number of shoots per vine was counted. Vines were hand harvested in mid- to late-September of each year of the study. The number of clusters and crop weight per vine were recorded.

One to 2 days prior to harvest, samples of approximately 100 berries were collected by harvesting two apical berries from approximately 50 clusters per vine, for each of eight vines per replicated plot. The berry samples were weighed, crushed, and juice-soluble solids were measured using a hand-held temperature compensating refractometer (Bausch and Lomb model 39-45-01, Rochester, NY). The $\mathrm{pH}$ of juice from macerated fruit was determined using a $\mathrm{pH}$ meter (Corning model 430, Corning, NY). To measure juice color, 100-ml aliquots of juice from each sample were placed into a $60^{\circ} \mathrm{C}$ water bath. Once the sample temperature had reached $60^{\circ} \mathrm{C}$, $1 \mathrm{ml}$ of $1 \%$ pectinase was added, the samples were stirred for $25 \mathrm{~min}$ at $60^{\circ} \mathrm{C}$, then filtered through a commercial dairy filter. Five $\mathrm{ml}$ of the filtered juice was brought to a volume of $100 \mathrm{ml}$ with MacUlvaines buffer solution $(\mathrm{pH} \mathrm{3.2)}$. Five $\mathrm{ml}$ of this solution was pipetted into a cuvette, and absorbance at 520 and $430 \mathrm{~nm}$ was deter- mined with a spectrophotometer (Unicam Spectronic 20, Rochester, NY). Absorbance at 520 indicates the intensity of red color in juice, a desirable character; whereas the ratio of absorbance at 520 to $430 \mathrm{~nm}$ is used to assess browning, or relative intensity of oxidized phenolics in juice, with ratios of less than 1.60 being undesirable (J. Jugovich, National Grape Cooperative, unpublished data). To determine total acidity, $10 \mathrm{ml}$ of the filtered juice was brought to $50 \mathrm{ml}$ with distilled water and titrated to $\mathrm{pH} 8.1$ with $0.1 \mathrm{~N}$ $\mathrm{NaOH}$.

The three pruning treatments created three levels of cropping intensity ( $\mathrm{kg}$ of fruit per vine). Within the sprayed and unsprayed treatments, the relationship between crop load and brix levels was examined by regression analysis after confirming that variances of yield and brix were homogeneous for the different pruning treatments (14). Data were therefore pooled for simple linear regression of brix against yield for sprayed and unsprayed vines (REGRESS, Minitab version 8.0, Minitab Inc., State College, PA).

\section{RESULTS AND DISCUSSION}

From 27 to $43 \%$ of conidia in suspensions applied to glass slides germinated, with coefficients of variation that ranged from 24 to $37 \%$. This resulted in the early establishment of a uniform and relatively high level of foliar infection (five leaves per vine within 10 days of inoculation) in each year of the study. Nonetheless, dis-

Table 1. Incidence and severity of powdery mildew on sprayed and unsprayed Concord grapevines under three different pruning systems

\begin{tabular}{|c|c|c|c|c|c|c|}
\hline Year & $\begin{array}{l}\text { Pruning } \\
\text { system }\end{array}$ & $\begin{array}{l}\text { Fungicide } \\
\text { treatment }^{\mathrm{a}}\end{array}$ & $\begin{array}{l}\text { Infected leaves } \\
\text { per shoot }^{b}\end{array}$ & $\begin{array}{l}\% \text { Leaf surface } \\
\text { infected }^{\mathrm{b}}\end{array}$ & $\begin{array}{l}\text { \% Clusters } \\
\text { infected }^{b}\end{array}$ & $\begin{array}{c}\text { \% Cluster surface } \\
\text { infected }^{b}\end{array}$ \\
\hline \multirow[t]{6}{*}{1992} & \multirow[t]{2}{*}{ Balanced } & Sprayed & $0.2^{*}$ & $6.9^{*}$ & $0.0^{*}$ & 0.0 \\
\hline & & Unsprayed & 7.8 & 35.4 & 3.5 & 0.1 \\
\hline & \multirow[t]{2}{*}{80 Node } & Sprayed & $1.3 *$ & $6.2^{*}$ & $0.0 *$ & 0.0 \\
\hline & & Unsprayed & 9.7 & 27.8 & 10.5 & 1.2 \\
\hline & \multirow[t]{2}{*}{ Minimal } & Sprayed & $0.7 *$ & $5.9^{*}$ & $0.0 *$ & 0.0 \\
\hline & & Unsprayed & 7.8 & 39.5 & 6.5 & 0.3 \\
\hline \multirow[t]{6}{*}{1993} & \multirow[t]{2}{*}{ Balanced } & Sprayed & $3.4 *$ & $9.3 *$ & $0.0 *$ & 0.0 \\
\hline & & Unsprayed & 6.1 & 21.6 & 2.0 & 0.1 \\
\hline & \multirow[t]{2}{*}{80 Node } & Sprayed & $2.8 *$ & $11.3^{*}$ & $0.0 *$ & 0.0 \\
\hline & & Unsprayed & 8.7 & 22.8 & 3.2 & 0.2 \\
\hline & \multirow[t]{2}{*}{ Minimal } & Sprayed & $2.5^{*}$ & $8.9 *$ & $0.0 *$ & 0.0 \\
\hline & & Unsprayed & 7.3 & 16.6 & 2.5 & 0.4 \\
\hline \multirow[t]{6}{*}{1994} & \multirow[t]{2}{*}{ Balanced } & Sprayed & $3.3^{*}$ & $25.7 *$ & $1.7 *$ & $0.1 *$ \\
\hline & & Unsprayed & 8.1 & 64.5 & 50.0 & 5.5 \\
\hline & \multirow[t]{2}{*}{80 Node } & Sprayed & $4.8 *$ & $30.7 *$ & $4.2 *$ & $0.1 *$ \\
\hline & & Unsprayed & 9.6 & 78.2 & 55.0 & 11.5 \\
\hline & \multirow{2}{*}{ Minimal } & Sprayed & $6.2 *$ & $39.2 *$ & $0.8 *$ & $0.3 *$ \\
\hline & & Unsprayed & 10.0 & 66.6 & 51.7 & 8.3 \\
\hline \multirow[t]{6}{*}{1995} & \multirow[t]{2}{*}{ Balanced } & Sprayed & $2.0^{*}$ & $9.7 *$ & $1.3^{*}$ & $0.3^{*}$ \\
\hline & & Unsprayed & 5.1 & 28.6 & 50.0 & 5.6 \\
\hline & \multirow[t]{2}{*}{80 Node } & Sprayed & $1.9 *$ & $10.2 *$ & $0.0^{*}$ & $0.0 *$ \\
\hline & & Unsprayed & 5.4 & 30.8 & 50.0 & 4.7 \\
\hline & \multirow[t]{2}{*}{ Minimal } & Sprayed & $1.7 *$ & $8.4 *$ & $1.3 *$ & $0.1 *$ \\
\hline & & Unsprayed & 7.3 & 22.3 & 55.0 & 7.5 \\
\hline
\end{tabular}

${ }^{a}$ Sprayed vines were treated with myclobutanil (112 g/ha) four times per season at 2-wk intervals, beginning just prior to first bloom. Each season, when shoots were 10 to $15 \mathrm{~cm}$ long, unsprayed vines were inoculated with a suspension containing 105 conidia per milliliter of Uncinula necator in order to promote uniform levels of primary infection.

${ }^{\mathrm{b}}$ Immediately before harvest, foliar disease incidence was recorded as the number of infected leaves per shoot on five shoots on each of eight vines per replicate plot. Foliar disease severity was recorded as the percentage of the leaf surface colonized by $U$. necator on each infected leaf. The percentage of the cluster surface colonized was also recorded on 10 fruit clusters on each of eight vines per plot. "*”" Indicates a significant difference in parameter between sprayed and unsprayed treatment at $P=0.05$ according to Student's $t$-distribution test. 
ease incidence and severity on fruit of unsprayed vines varied considerably at harvest among the 4 years of the study (Table 1). The fungicide spray program effectively suppressed powdery mildew on fruit at all three cropping levels throughout the study (Table 1), but allowed foliar infection to progress to varying levels, depending on the year, by the time of harvest (Table 1). Fruit infection was not always commensurate with the incidence or severity of foliar infection (Table 1). Instead, fruit infection was most severe in 1994 and 1995, when ascosporic infection periods, i.e., $>2.5 \mathrm{~mm}$ rain coincident with temperatures above $10^{\circ} \mathrm{C}$ between prebloom and fruit set $(2,3,5)$, were most numerous. The number of ascosporic infection periods between prebloom and fruit set was 2 in 1992, 4 in 1993, 10 in 1994, and 8 in 1995.
It is widely presumed that conidia originating from foliar colonies are the principal source of infection for fruit clusters, and while it is possible that the above weather conditions favored secondary infection by conidia, this is difficult to reconcile with the deleterious effects of rainfall and free water on conidial germination and infection (15). Direct infection of fruit by ascospores may be an unrecog-

Table 2. Effects of powdery mildew on growth and yield of Concord grapevines under three different pruning systems

\begin{tabular}{|c|c|c|c|c|c|c|c|}
\hline Year & $\begin{array}{c}\text { Pruning } \\
\text { system }\end{array}$ & $\begin{array}{l}\text { Fungicide } \\
\text { treatment }^{\mathrm{a}}\end{array}$ & $\begin{array}{c}\text { Nodes with } \\
\text { periderm }\end{array}$ & $\begin{array}{c}\text { Shoots per } \\
\text { node }\end{array}$ & $\begin{array}{l}\text { Crop per } \\
\text { vine (kg) }\end{array}$ & $\begin{array}{l}\text { Weight per } \\
\text { cluster (g) }\end{array}$ & $\begin{array}{c}\text { Weight per } \\
\text { berry }(\mathrm{g})\end{array}$ \\
\hline \multirow[t]{6}{*}{1992} & \multirow[t]{2}{*}{ Balanced } & Sprayed & 499 & 1.22 & 12.1 & 95.1 & 2.69 \\
\hline & & Unsprayed & 457 & 1.24 & 12.3 & 94.5 & 2.80 \\
\hline & \multirow[t]{2}{*}{80 Node } & Sprayed & 532 & 1.13 & 15.0 & 80.9 & 2.51 \\
\hline & & Unsprayed & 468 & 1.15 & 15.9 & 84.1 & 2.57 \\
\hline & \multirow[t]{2}{*}{ Minimal } & Sprayed & $589^{*}$ & 1.07 & 13.8 & 78.4 & 2.57 \\
\hline & & Unsprayed & 479 & 1.05 & 14.7 & 82.9 & 2.70 \\
\hline \multirow[t]{6}{*}{1993} & \multirow[t]{2}{*}{ Balanced } & Sprayed & 480 & 1.07 & 5.8 & 74.2 & 2.57 \\
\hline & & Unsprayed & 465 & 1.06 & 5.8 & 72.7 & 2.58 \\
\hline & \multirow{2}{*}{80 Node } & Sprayed & 553 & 0.95 & 8.9 & 66.8 & 2.52 \\
\hline & & Unsprayed & 546 & 0.98 & 9.0 & 66.2 & 2.54 \\
\hline & \multirow[t]{2}{*}{ Minimal } & Sprayed & $428 *$ & 0.88 & 18.3 & 36.8 & 1.97 \\
\hline & & Unsprayed & 394 & 0.94 & 18.0 & 37.7 & 2.04 \\
\hline \multirow[t]{6}{*}{1994} & \multirow{2}{*}{ Balanced } & Sprayed & $576^{*}$ & 1.30 & 13.0 & 84.4 & 2.70 \\
\hline & & Unsprayed & 499 & 1.28 & 11.8 & 85.8 & 2.85 \\
\hline & \multirow[t]{2}{*}{80 Node } & Sprayed & $590^{*}$ & 1.17 & 14.3 & 78.8 & 2.65 \\
\hline & & Unsprayed & 509 & 1.15 & 14.5 & 78.1 & 2.72 \\
\hline & \multirow[t]{2}{*}{ Minimal } & Sprayed & $551^{*}$ & 1.59 & 18.8 & 44.8 & 2.26 \\
\hline & & Unsprayed & 445 & 1.49 & 18.3 & 43.0 & 2.31 \\
\hline \multirow{6}{*}{1995} & \multirow[t]{2}{*}{ Balanced } & Sprayed & 571 & 1.07 & 12.4 & 84.2 & 2.70 \\
\hline & & Unsprayed & 501 & 1.10 & 12.3 & 85.8 & 2.72 \\
\hline & \multirow[t]{2}{*}{80 Node } & Sprayed & $565^{*}$ & 1.01 & 12.9 & 80.6 & 2.73 \\
\hline & & Unsprayed & 501 & 0.98 & 12.2 & 77.4 & 2.63 \\
\hline & \multirow{2}{*}{ Minimal } & Sprayed & 470 & 1.16 & 14.6 & 36.9 & 2.30 \\
\hline & & Unsprayed & 438 & 1.19 & 14.3 & 37.7 & 2.37 \\
\hline
\end{tabular}

a Sprayed vines were treated with myclobutanil (112 g/ha) four times per season at 2-wk intervals, beginning just prior to first bloom. Each season, when shoots were 10 to $15 \mathrm{~cm}$ long, unsprayed vines were inoculated with a suspension containing 105 conidia per milliliter of Uncinula necator in order to promote uniform levels of primary infection. "**" Indicates a significant difference in parameter between sprayed and unsprayed treatment at $P=0.05$ according to Student's $t$-distribution test.

Table 3. Effects of powdery mildew on various quality parameters of juice from berries of Concord grapevines under three different pruning systems

\begin{tabular}{|c|c|c|c|c|c|c|c|c|}
\hline Year & $\begin{array}{c}\text { Pruning } \\
\text { system }\end{array}$ & $\begin{array}{l}\text { Fungicide } \\
\text { treatment }\end{array}$ & $\operatorname{Brix}(\%)^{a}$ & $\mathbf{p H}^{\mathbf{a}}$ & $\begin{array}{l}\text { Absorbance } \\
\text { at } 520 \text { nm}^{\text {a }}\end{array}$ & $\begin{array}{c}\text { Absorbance at } \\
430 \mathbf{n m}^{\mathrm{a}}\end{array}$ & Ratio $A_{520}: A_{430}{ }^{\mathrm{a}}$ & $\begin{array}{c}\text { Total acidity } \\
(\mathrm{g} / \mathrm{liter})^{\mathrm{a}}\end{array}$ \\
\hline \multirow[t]{6}{*}{1992} & \multirow[t]{2}{*}{ Balanced } & Sprayed & $16.8^{*}$ & 2.77 & 10.22 & $6.82 *$ & 1.484 & $13.95^{*}$ \\
\hline & & Unsprayed & 16.0 & 2.77 & 8.85 & 6.11 & 1.448 & 14.25 \\
\hline & \multirow[t]{2}{*}{80 Node } & Sprayed & $15.8^{*}$ & 2.76 & $8.50 *$ & 5.89 & $1.439 *$ & $13.80^{*}$ \\
\hline & & Unsprayed & 14.6 & 2.74 & 6.72 & 5.31 & 1.264 & 14.55 \\
\hline & \multirow[t]{2}{*}{ Minimal } & Sprayed & $16.1^{*}$ & 2.81 & $9.01 *$ & $6.20^{*}$ & $1.454 *$ & $14.33^{*}$ \\
\hline & & Unsprayed & 15.3 & 2.78 & 7.43 & 5.42 & 1.362 & 14.63 \\
\hline \multirow[t]{6}{*}{1993} & \multirow{2}{*}{ Balanced } & Sprayed & 18.2 & 3.14 & 20.96 & 10.19 & 2.056 & $12.68 *$ \\
\hline & & Unsprayed & 18.1 & 3.14 & 22.36 & 10.55 & 2.120 & 12.90 \\
\hline & \multirow{2}{*}{80 Node } & Sprayed & 17.9 & 3.11 & 20.79 & 10.25 & 2.036 & $12.30^{*}$ \\
\hline & & Unsprayed & 17.5 & 3.12 & 20.58 & 10.08 & 2.052 & 12.76 \\
\hline & \multirow[t]{2}{*}{ Minimal } & Sprayed & $15.1 *$ & 3.13 & $10.46^{*}$ & $5.76^{*}$ & $1.807 *$ & $11.70 *$ \\
\hline & & Unsprayed & 14.6 & 3.05 & 8.43 & 4.80 & 1.746 & 11.86 \\
\hline \multirow[t]{6}{*}{1994} & \multirow[t]{2}{*}{ Balanced } & Sprayed & 17.3 & 3.20 & 15.70 & 8.14 & $1.918 *$ & 13.58 \\
\hline & & Unsprayed & 17.3 & 3.19 & 15.95 & 8.38 & 1.864 & 13.58 \\
\hline & \multirow[t]{2}{*}{80 Node } & Sprayed & $17.1^{*}$ & 3.18 & 13.76 & 7.07 & 1.920 & $13.20 *$ \\
\hline & & Unsprayed & 16.4 & 3.20 & 13.09 & 6.76 & 1.912 & 13.65 \\
\hline & \multirow[t]{2}{*}{ Minimal } & Sprayed & $15.1 *$ & 3.19 & $8.24 *$ & $4.68^{*}$ & 1.713 & $12.90 *$ \\
\hline & & Unsprayed & 14.3 & 3.15 & 7.01 & 4.11 & 1.688 & 13.20 \\
\hline \multirow{6}{*}{1995} & \multirow[t]{2}{*}{ Balanced } & Sprayed & 17.5 & 3.40 & 21.37 & 10.27 & 2.084 & 11.10 \\
\hline & & Unsprayed & 17.5 & 3.38 & 22.08 & 10.55 & 2.090 & 11.25 \\
\hline & \multirow[t]{2}{*}{80 Node } & Sprayed & 17.8 & 3.41 & $21.56^{*}$ & $10.24 *$ & 2.111 & $10.95^{*}$ \\
\hline & & Unsprayed & 17.1 & 3.36 & 19.78 & 9.43 & 2.094 & 11.55 \\
\hline & \multirow{2}{*}{ Minimal } & Sprayed & 16.5 & 3.39 & $23.75 *$ & $8.30 *$ & 2.005 & 10.65 \\
\hline & & Unsprayed & 16.3 & 3.33 & 15.02 & 7.56 & 1.989 & 10.80 \\
\hline
\end{tabular}

a “*” Indicates a significant difference in parameter between sprayed and unsprayed treatment at $P=0.05$ according to Student's $t$-distribution test. USDA standard for Concord grape juice requires a minimum of $15.0 \%$ Brix. National Grape Cooperative requires a minimum ratio of $A_{520}: A_{430}$ of 1.60 for premium grade Concord grape juice. 


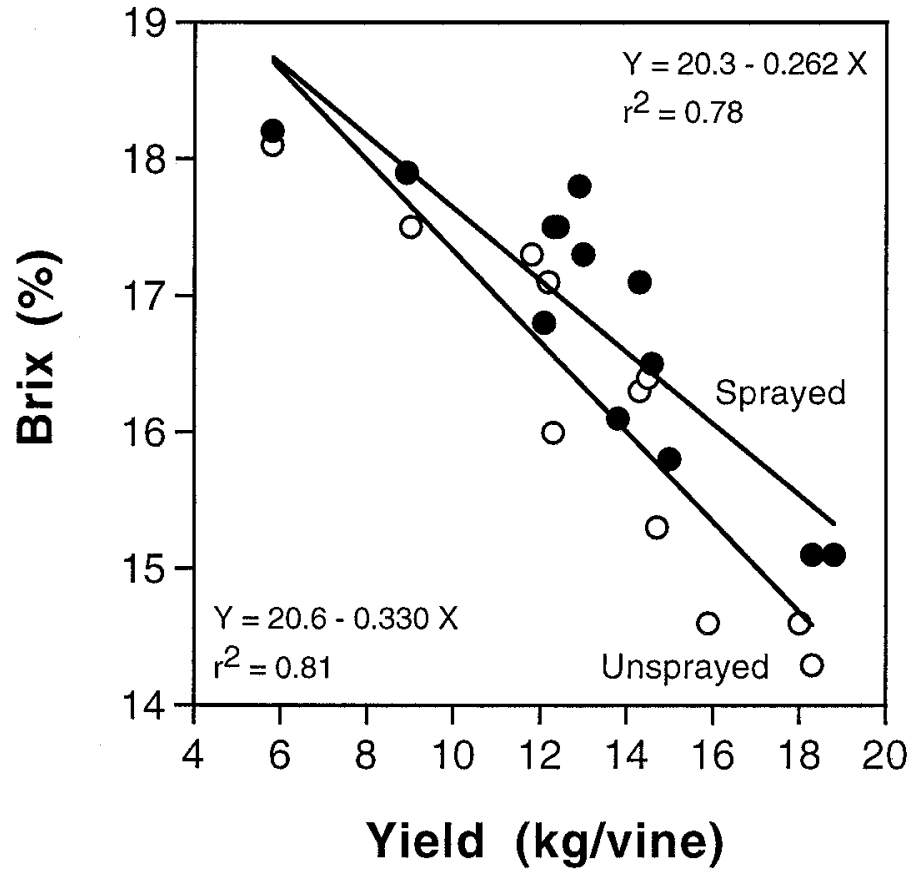

Fig. 1. Relationship between yield ( $\mathrm{kg}$ of berries per vine) and brix juice (percent of soluble solids at harvest) for vines sprayed with fungicides to control powdery mildew (Uncinula necator) versus vines on which powdery mildew was not controlled. The slope coefficient of the regression for unsprayed vines is significantly greater than that for sprayed vines at $P=0.01$. The y-intercepts of the two regressions are equivalent at $P=0.10$.

nized, but important contributor to severe powdery mildew on Concord fruit in years where ascospores are released by multiple rain events during a critical period of fruit susceptibility $(5,6)$.

Of all of the vine growth and yield parameters measured, powdery mildew affected only the total number of nodes with periderm per vine (Table 2). The reduction in the number of nodes with periderm on unsprayed vines ranged from 8 to $19 \%$ relative to the sprayed vines. In 1992 and 1993 , the reduction was observed only on minimally pruned vines. Nevertheless, in 1994, the year in which powdery mildew was most severe, the reduction was observed in all three pruning treatments (Table 2). In no case did the reduction of nodes with periderm translate into a reduction of yield the following year, measured as $\mathrm{kg}$ of fruit per vine (Table 2). Nonetheless, there was a significant impact of powdery mildew on juice quality, measured as sugar accumulation, intensity of red color (absorbance at $520 \mathrm{~nm}$ ), browning (ratio of absorbance at 520 to absorbance at $430 \mathrm{~nm}$ ), and acidity (Table 3 ). In 1993 and 1994, years in which brix levels were low across the Lake Erie region, the failure to control powdery mildew on minimally pruned vines reduced brix levels below 15.0, the minimal level normally accepted by processors. This effect also was observed on 80-node vines in 1992.

The failure to control powdery mildew results in a chronic reduction in vine growth, measured as the number of nodes with periderm, but there appears to be an excessive number of nodes produced, and the reduction in node formation does not significantly affect yield. We found no indication that powdery mildew affected bud survival or vigor, measured as the number of shoots produced per node. The most significant and substantial impacts of powdery mildew on Concord grapevines are in the reduction of brix, and in the degradation of juice quality. This impact increases with yield per vine as one moves from balanced pruned vines to 80-node vines, and finally to minimally pruned (Tables 2 and 3). When brix levels were regressed against yield for sprayed and unsprayed vines, brix declined more steeply with increasing yield on unsprayed vines than on sprayed vines (Fig. 1). The regression equations (with standard errors in parentheses) for sprayed and unsprayed vines, respectively, were: $Y=20.3(0.186)$ - $0.262(0.0134) X, r^{2}=0.78$ (equation 1 ); and $Y=20.6(0.209)-0.330(0.0152) X, r^{2}$ $=0.81$ (equation 2) where $Y=$ brix at harvest, and $X=\mathrm{kg}$ fruit per vine at harvest.

The Y-intercepts of the regressions were similar for sprayed and unsprayed vines $(P=$ 0.10 ), while the slope coefficient of the regression for unsprayed vines was greater than that of the sprayed vines at $P=0.01$ (Fig. 1).

Powdery mildew appears to affect sugar accumulation in grapevine in a manner similar to other chronic stress factors such as drought or defoliation $(10,12)$, i.e., the impact may be negligible when vines are lightly cropped, but may be significant as yield is increased. Therefore, the effect of powdery mildew on brix may be of greatest concern when yield is maximized under poor disease control.
LITERATURE CITED

1. Gadoury, D. M., and Pearson, R. C. 1988 Initiation, development, dispersal, and survival of cleistothecia of Uncinula necator in New York vineyards. Phytopathology 78:1413-1421.

2. Gadoury, D. M., and Pearson, R. C. 1990. Ascocarp dehiscence and ascospore discharge in Uncinula necator. Phytopathology 80:393-401.

3. Gadoury, D. M., and Pearson, R. C. 1990 Germination of ascospores and infection of Vitis by Uncinula necator. Phytopathology 80:1198-1203.

4. Gadoury, D. M., and Pearson, R. C. 1991. Heterothallism and pathogenic specialization in Uncinula necator. Phytopathology 81:1287-1293.

5. Gadoury, D. M., Pearson, R. C., Seem, R. C. and Park, E. W. 1997. Integrating the control programs for fungal diseases of grapevine in the northeastern United States. Vitic. Enol. Sci. 52:140-147.

6. Gadoury, D. M., and Seem, R. C. 1995. Development of ontogenic resistance to powdery mildew (Uncinula necator) in fruit of Concord grapevines. Phytopathology 85:1149.

7. Gadoury, D. M., Seem, R. C., Magarey, P. A., Emmett, R., and Magarey, R. 1997. Effects of environment and fungicides on epidemics of grape powdery mildew: Considerations for practical model development and disease management. Vitic. Enol. Sci. 52:225-229.

8. Gadoury, D. M., Seem, R. C., and Wilcox, W. F. 1997. Early ontogenic resistance to powdery mildew in Chardonnay and Riesling grapes. Phytopathology 87:S31.

9. Hickey, K. D. 1991. Fungicide benefits assessment. Fruit and Nut Crops-East. National Pesticide Impact Assessment Program.

10. Lakso, A. N., Denning, S. S., Dunst, R., and Fendinger, A. G. 1997. Physiological comparisons of minimally and conventionally pruned Concord grapevines. Am. J. Enol. Vitic. 48:250.

11. Lakso, A. N., Pratt, C. S., Pearson, R. C. Pool, R. M., Seem, R. C., and Welser, M. J. 1982. Photosynthesis, transpiration, and water use efficiency in mature grape leaves infected with Uncinula necator (powdery mildew). Phytopathology 72:232-236.

12. Martinson, T. E., Dunst, R., Lakso, A., and English-Loeb, G. 1997. Impact of feeding injury by Eastern Grape Leafhopper (Homoptera:Cicadellidae) on yield and juice quality of Concord grapes. Amer. J. Enol. Vitic. 48:291-302.

13. Muza, A. J., and Travis, J. W. 1996. Evaluation of fungicides for control of powdery mildew on grapes, 1995. Fungic. Nematic. Tests 51:67.

14. Neter, J., and Wasserman, W. 1974. Applied Linear Statistical Models. Richard D. Irwin Co., Homewood, IL.

15. Pearson, R. C., and Gadoury, D. M. 1992. Grape powdery mildew, in: Plant Diseases of International Importance. Vol. III, Diseases of Fruit Crops. J . Kumar, H. S. Chaube, U. S. Singh, and A. N. Mukhopadhyay, eds. Prentice Hall, Englewood Cliffs, NJ.

16. Pearson, R. C., and Goheen, A. C. 1988 Compendium of Grape Diseases. American Phytopathogical Society, St. Paul, MN.

17. Pearson, R. C., Seem, R. C., and Eisensmith, S. P. 1985. Assessment of Pests, Losses They Cause, and Pest Management Strategies for Great Lakes/Eastern Grapes. NY. Agric. Exp. Stn. Special Rep.

18. Ramsdell, D. C. 1996. Foliar fungicides to control fruit rots, Phomopsis rachis lesions, and downy and powdery mildews, 1995. Fungic. Nematic. Tests 51:68

19. Taschenberg, E. F., and Pearson, R. C. 1982. Evaluation of fungicides for control of powdery mildew of Concord grapes, 1981. Fungic. Nematic. Tests 37:49. 